\title{
ANALISA GANGGUAN HUBUNG SINGKAT SATU FASA KE TANAH PADA JARINGAN DISTRIBUSI 20 KV PT. PLN (PERSERO) SEBATIK MENGGUNAKAN SOFTWARE ETAP POWER STATION 12.6.0
}

\author{
Tomi Samin \\ Jurusan Teknik Elektro Universitas Borneo Tarakan, Tarakan, Kalimantan Utara, Indonesia \\ email: tomi.elektro@gmail.com
}

\begin{abstract}
The distribution system of medium voltage 20 $k V$ is a means of plant to the consumer. But in reality the distribution system is often impaired among which the most common is the one-phase short circuit to ground. Therefore, short circuit analysis is required to determine a reliable protection system settings to localize the disorder. Equipment protection system is used for medium power distribution system is more current relays and relay circuit ground, the relay function PMT instructed to open the event of disruption, so that the affected tissue can be separated from the network. In this final project will discuss about the analysis of single phase short circuit to ground that is then used for the determination of the protection relay settings on the secondary power distribution system PT. PLN Sebatik.
\end{abstract}

Keywords-The distribution system, the one-phase short circuit to ground, relay settings

Intisari-Sistem distribusi tegangan menengah $20 \mathrm{kV}$ merupakan alat tanam bagi konsumen. Namun pada kenyataannya sistem distribusi sering mengalami gangguan antara yang paling umum adalah hubung singkat satu fase ke ground. Oleh karena itu, analisis hubungan arus pendek diperlukan untuk mengetahui pengaturan sistem proteksi yang andal untuk melokalisasi gangguan tersebut. Sistem proteksi peralatan yang digunakan untuk sistem distribusi tenaga medium lebih banyak relay arus dan relay circuit ground, fungsi relay PMT diinstruksikan untuk membuka acara gangguan, sehingga jaringan yang terkena dapat dipisahkan dari jaringan. Pada tugas akhir ini akan dibahas tentang analisis hubung singkat fase tunggal ke ground yang kemudian digunakan untuk penentuan setting proteksi proteksi pada sistem distribusi tenaga sekunder PT.PLN Sebatik.

Kata Kunci-Sistem distribusi, sirkuit pendek satu fasa ke ground, pengaturan relay

\section{PENDAhULUAN}

Suatu gangguan di dalam peralatan listrik didefinisikan sebagai terjadinya suatu kerusakan di dalam jaringan listrik yang menyebabkan aliran arus listrik keluar dari saluran yang seharusnya. Hubung singkat merupakan suatu hubungan abnormal pada impedansi yang relatif rendah terjadi secara kebetulan atau disengaja antara dua titik yang mempunyai potensial yang berbeda. Untuk mengatasi gangguan tersebut, perlu dilakukan analisis hubung singkat sehingga sistem Proteksi yang tepat pada Sistem Tenaga Listrik dapat ditentukan. Analisis hubung singkat adalah analisis yang mempelajari kontribusi arus gangguan hubung singkat yang mungkin mengalir pada setiap cabang didalam sistem sewaktu gangguan hubung singkat yang mungkin terjadi di dalam sistem tenaga listrik. Berdasarkan kesimetrisannya, gangguan terdiri dari gangguan simetris dan asimetris. Hubung singkat terjadi akibat dari faktor internal dan faktor eksternal.

Penelitian ini bertujuan untuk menentukan arus hubung singkat gangguan satu fasa ke tanah, dan tingkat tegangan busbar selama gangguan pada PT. PLN Sebatik untuk menentukan setelan relai arus lebih dan relai hubung tanah, agar dapat menjadi bahan pertimbangan bagi PT.PLN Sebatik untuk memperbaiki kinerja sistem proteksi agar dapat menjaga kontinuitas pelayanan daya kepada konsumen.

\section{LANDASAN TEORI}

A. Sistem Distribusi Tenaga Listrik

Sistem tenaga listrik terdiri atas tiga bagian utama yaitu sistem pembangkitan, sistem transmisi dan sistem distribusi. Dari ketiga sistem tersebut, sistem distribusi merupakan bagian yang letaknya paling dekat dengan konsumen, fungsinya adalah menyalurkan energi listrik dari distribusi ke konsumen. Adapun bagian-bagian dari sistem distribusi tenaga listrik adalah distribusi, jaringan primer/jaringan tegangan menengah (JTM), transformator distribusi, jaringan sekunder/jarimgan tegangan rendah (JTR).

B. Sistem Distribusi $20 \mathrm{kV}$

Keluaran dari trafo daya dikumpulkan dulu pada Bus 20 KV di kubikel Gardu Induk untuk kemudian di distribusikan melalui beberapa penyulang $20 \mathrm{KV}$ ke konsumen dengan jaringan berupa Saluran Udara Tegangan Menengah (SUTM) atau Saluran Kabel Tegangan Menengah (SKTM). Bila terjadi gangguan itu biasanya pada sambungan yang akan merupakan gangguan permanen.

\section{Klasifikasi Sistem Jaringan Distribusi}

Jaringan distribusi dikategorikan kedalam beberapa jenis, Tegangan pengenalnya dan Konfigurasi jaringan primer. Dalam kinfigurasi jaringan primer ada beberapa bagian yaitu Jaringan Distribusi Pola Radial, Jaringan Distribusi Pola loop, Jaringan Distribusi Pola Grid, Jaringan Distribusi Pola Spindel 


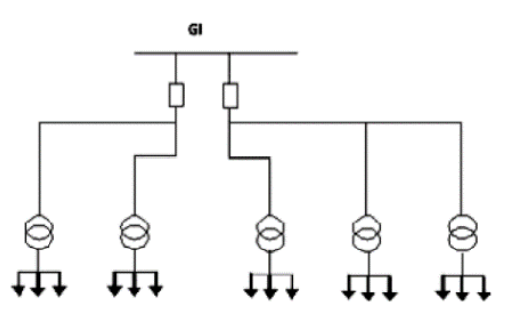

Gambar 1. Jaringan Distribusi Pola Radial

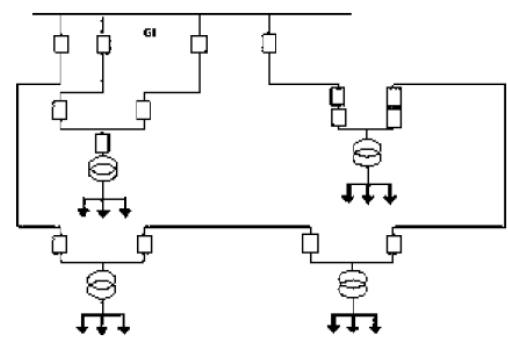

Gambar 2. Jaringan Distribusi Pola Loop

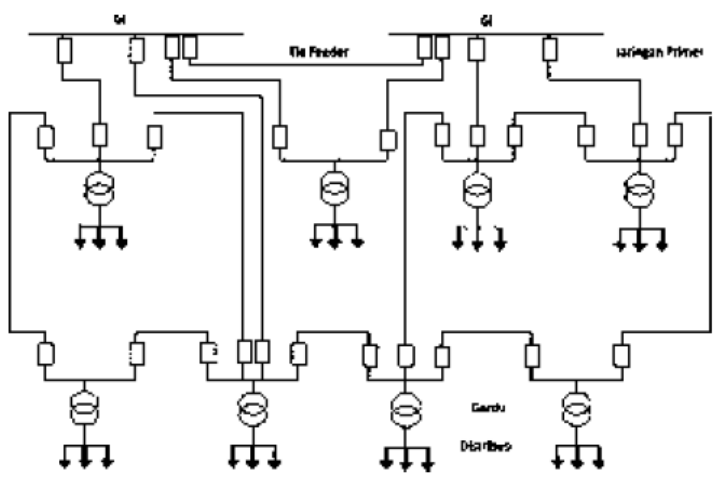

Gambar 3. Jaringan Distribusi Pola Grid

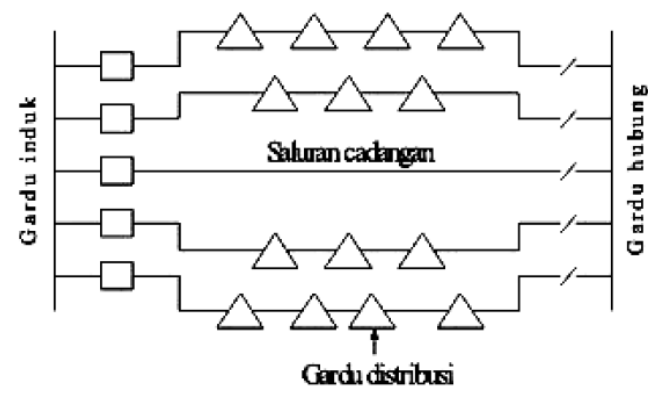

Gambar 4. Jaringan Distribusi Pola Spindel

D. Gangguan Hubung Singkat

Gangguan hubung singkat dapat juga terjadi akibat adanya isolasi yang tembus atau rusak karena tidak tahan terhadap tegangan lebih, baik yang berasal dari dalam (Tegangan lebih dan arus tak normal) maupun yang berasal dari luar (akibat sambaran petir). Bila gangguan hubung singkat dibiarkan berlangsung dengan lama pada suatu sistem daya, banyak pengaruh-pengaruh yang tidak diinginkan yang dapat terjadi. Ada dua jenis gangguan berdasarkan lama waktunya yaitu gangguan permanen dan gangguan temporer. Gangguan juga dapat dibedakan berdasarkan kesimetrisan yaitu simetri dan tidak simetri.
E. Komponen Simetris

Menurut teorema Fortescue, tiga fasor tak seimbang dari sistem tiga fasa dapat diuraikan menjadi tiga sistem fasor yang seimbang. Himpunan seimbang komponen itu adalah komponen urutan positif, komponen urutan negatif dan komponen urutan nol.

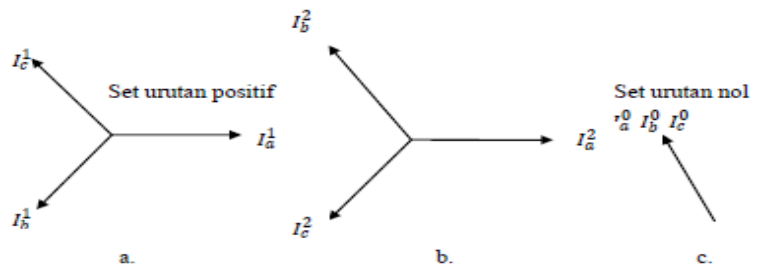

Gambar 5. Representasi komponen simetris

Dengan aturan arah putaran fasor berlawanan dengan arah jarum jam, ketiga fasor dituliskan sebagai:

$$
\begin{aligned}
& \text { Ia } 1=\text { Ia } 1 \angle 0^{\circ}=\text { Ia } 1 \\
& \text { Ib } 1=I a 1 \angle 240^{\circ}=\text { a I I } 1 \\
& \text { Ic } 1=I a 1 \angle 120^{\circ}=\text { aI } 1
\end{aligned}
$$

F. Gangguan Hubung Singkat Satu Fasa ke Tanah

Hubung singkat satu fasa ke tanah adalah gangguan hubung singkat yang terjadi karena flashover antara penghantar fasa dan tanah (tiang travers atau kawat tanah pada SUTM). Gangguan ini bersifat temporer, tidak ada kerusakan yang permanen di titik gangguan. Pada gangguan yang tembusnya adalah isolasi udaranya, oleh karena itu tidak ada kerusakan yang permanen. Setelah arus gangguannya terputus, misalnya karena terbukanya circuit breaker oleh relai pengamannya, peralatan atau saluran yang terganggu tersebut siap dioperasikan kembali. Jika terjadi gangguan satu fasa ke tanah, arus gangguannya hampir selalu lebih kecil daripada arus hubung singkat tiga fasa.

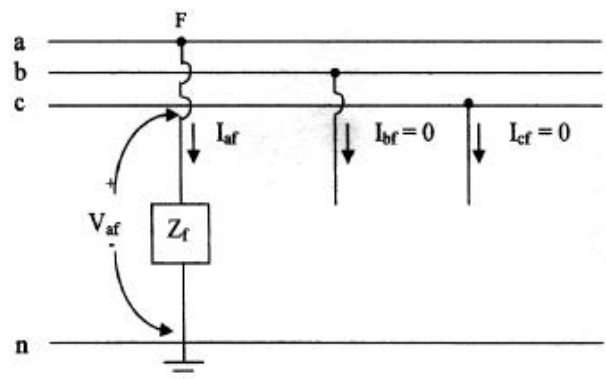

Gambar 6. Gangguan satu fasa ke tanah

Kondisi terminalnya sebagai berikut :

$$
I b=0 ; I c=0 ; V a f=I a \cdot Z f ; V=0
$$

Untuk persamaan arus yang digunakan diperoleh dari komponen simetris arus :

$$
\begin{aligned}
& I a_{0}=1 / 3(I a+I b+I c)=1 / 3 I a \\
& I a_{1}=1 / 3(I a+a I b+a 2 I c)=1 / 3 I a \\
& I a_{2}=1 / 3(I a+a 2 I b+a I c)=1 / 3 I a
\end{aligned}
$$

Jadi,

$$
I a_{0}=I a_{1}=I a_{2}=1 / 3 I a
$$




\section{G. ETAP Power Station}

ETAP (Electric Transient and Analysis Program) merupakan suatu perangkat lunak yang mendukung sistem tenaga listrik. Perangkat ini mampu bekerja dalam keadaan offline untuk simulasi tenaga listrik, online untuk pengelolaan data real-time atau digunakan untuk mengendalikan sistem secara real-time. Fitur yang terdapat di dalamnya pun bermacam-macam antara lain fitur yang digunakan untuk menganalisa pembangkitan tenaga listrik, sistem transmisi maupun sistem distribusi tenaga listrik. ETAP dapat digunakan untuk membuat proyek sistem tenaga listrik dalam bentuk diagram satu garis dan jalur sistem pentanahan untuk berbagai bentuk analisis, antara lain: aliran daya, hubung singkat, starting motor, trancient stability, koordinasi relai proteksi dan sistem harmonisasi. Pada sistem tenaga listrik memiliki masing-masing elemen rangkaian yang dapat diedit langsung dari diagram satu garis dan atau jalur sistem pentanahan.

ETAP Power Station juga menyediakan fasilitas library yang akan mempermudah desain suatu sistem kelistrikan. Library ini dapat diedit atau dapat ditambahkan dengan informasi peralatan bila perlu. Beberapa hal yang perlu diperhatikan dalam bekerja dengan ETAP Power Station adalah One Line Diagram, Library, Standar yang dipakai, Study Case.

\section{H. Relai Arus Lebih/Overcurrent Relay (OCR)}

Prinsip kerja relay OCR adalah bedasarkan adanya arus lebih yang dirasakan relay, baik disebabkan adanya gangguan hubung singkat atau overload (beban lebih) untuk kemudian memberikan perintah trip ke PMT sesuai dengan karakteristik waktunya.

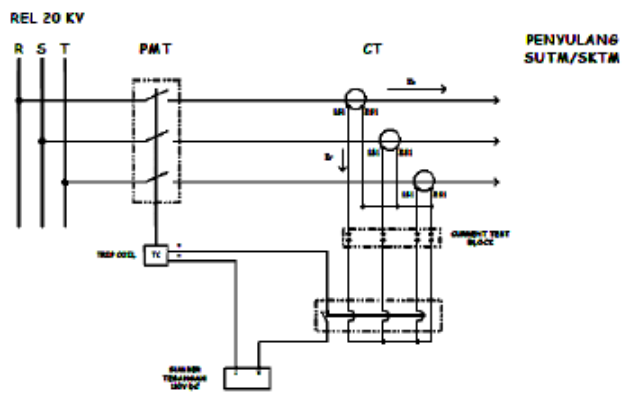

Gambar 7. Rangkaian pengawatan relay arus lebih (OCR)

Relai arus lebih merupakan relai pengaman yang bekerja karena adanya besaran arus relai ini terpasang pada jaringan tegangan tinggi, tegangan menegah juga pada transformator tenaga.

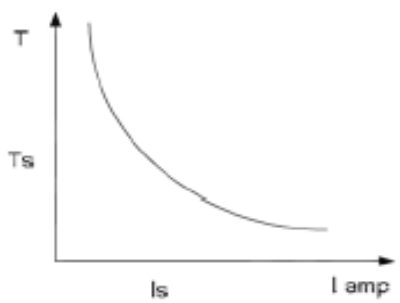

Gambar 8. Karakteristik Waktu Terbalik

Relai arus lebih memiliki setelan pick up dan setelan time dial (waktu kerja relai) . Pick up didefinisikan sebagai nilai arus minimum yang menyebabkan relai bekerja (Iset). Overcurrent Relay. Pada dasarnya batas penyetelan relai arus lebih relai tidak boleh bekerja pada saat beban maksimum. Arus settingnya harus lebih besar dari arus beban maksimumnya. Arus penyetelanya pun harus memperhaikan kesalahan pick up sesuai dengan British Standard Pick Up.

$$
\begin{aligned}
& I_{\text {set primer }}=I P=1,05 \times I_{\text {nominal }} \\
& I_{\text {set sekunder }}=I P \times 1 \text { Ratio } C T
\end{aligned}
$$

I. Relai Hubung Tanah/Ground Fault Relay (GFR)

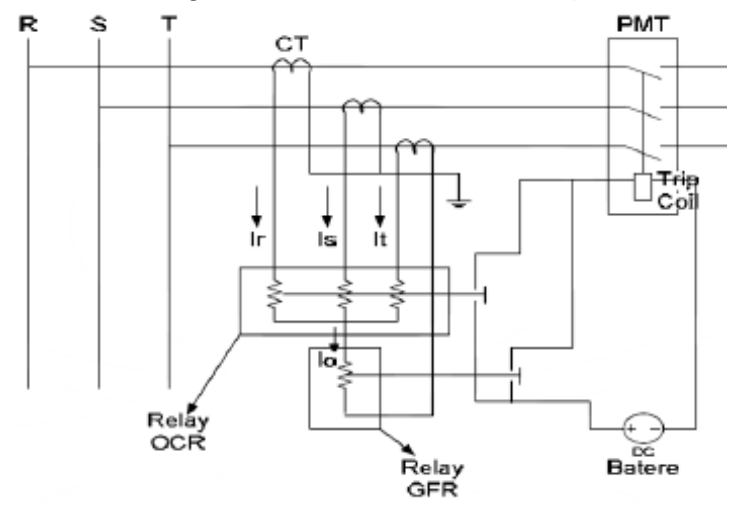

Gambar 9. Rangkaian Pengawatan Relai GFR

Prinsip kerja GFR adalah pada kondisi normal beban seimbang Ir, Is, It sama besar, sehingga pada kawat netral tidak timbul arus dan relay hubung tanah tidak dialiri arus. Bila terjadi ketidakseimbangan arus atau terjadi gangguan hubung singkat ke tanah, maka akan timbul arus urutan nol pada kawat netral, sehingga relay hubung tanah akan bekerja.

Relai hubung tanah merupakan relai pengaman yang bekerja karena adanya besar arus yang terpasang pada jaringan tegangan tinggi, tegangan menegah, juga pada pengaman trasformator tenaga. Penyetelan relay GFR pada sisi primer dan sisi sekunder transformator tenaga terlebih dahulu harus dihitung arus nominal transformator tenaga.

\section{METODE PENELITIAN}

Dalam penelitian ini lokasi yang diambil yaitu di PT. PLN (Persero) Sebatik Cabang Berau Kabupaten Nunukan. Penulis juga mengumpulkan data dari PT.PLN sebatik berupa data generator, data Transformator, data Kawat Penghantar, data Beban dan data Bus. Data-data yang dibutuhkan dalam penelitian ini adalah Diagram segaris (single line diagram) PT.PLN Sebatik, Data Busbar, Data pembangkit Data transformator, Data saluran penghantar, Data beban puncak PT.PLN Sebatik.

Dalam pengolahan data dilakukan beberapa tahap yaitu pengambilan data, membuat diagram segaris, memasukkan parameter kelistrikan kedalam tampilan perangkat editor ETAP Power Station 12.6.0, memasukkan simulasi aliran daya, melakukan simulasi arus hubung singkat satu fasa ketanah pada software ETAP Power Station 12.6.0 dan menganalisis hasil simulasi arus hubung singkat satu fase pada software ETAP Power Station 12.6.0 pada bus yang di tentukan. Peralatan yang digunakan pada penelitian ini adalah 
perangkat keras laptop dan software ETAP Power station 12.6.0.

Data Parameter Kelistrikan, Data beban, data pembangkit, Data Transformator :

A. Data-Data Pembangkit Tenaga Listrik PT.PLN Sebatik

Tabel I

Data Pembangkit yang Beroperasi

\begin{tabular}{|c|c|c|c|c|c|}
\hline Z & 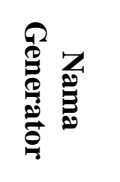 & Ė & 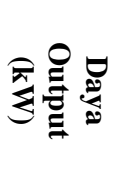 & 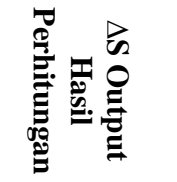 & 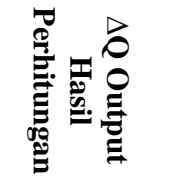 \\
\hline 1 & $\begin{array}{l}\text { DEUTZ } \\
\text { MWM }\end{array}$ & 1 & 290 & 341,1764706 & 177,4117647 \\
\hline 2 & $\begin{array}{l}\text { DEUTZ } \\
\text { MWM }\end{array}$ & 1 & 310 & 364,7058824 & 189,6470588 \\
\hline 3 & $\begin{array}{l}\text { MAN } \\
\text { D2842 }\end{array}$ & 1 & 300 & 352,9411765 & 183,5294118 \\
\hline 4 & $\begin{array}{l}\text { MAN } \\
\text { D2842 }\end{array}$ & 1 & 290 & 341,1764706 & 177,4117647 \\
\hline 5 & $\begin{array}{l}\text { MAN } \\
\text { D2842 }\end{array}$ & 1 & 300 & 352,9411765 & 183,5294118 \\
\hline 6 & $\begin{array}{l}\text { MAN } \\
\text { D2842 }\end{array}$ & 1 & 310 & 364,7058824 & 701,3574661 \\
\hline 7 & $\begin{array}{l}\text { MAN } \\
\text { D2842 }\end{array}$ & 1 & 0 & 0 & 0 \\
\hline 8 & PLTS & 1 & 0 & 0 & 0 \\
\hline 9 & PLTMG & 1 & 0 & 0 & 0 \\
\hline \multicolumn{2}{|c|}{ Total } & 9 & & 2117,647059 & 1612,8878 \\
\hline
\end{tabular}

$\operatorname{Cos} \varphi=0,85$

$\operatorname{Sin} \varphi=0,52$

Nilai daya kompleks dan daya reaktif dipengaruhi oleh besarnya nilai $\operatorname{Cos} \varphi$, daya Kompleks (S) dihitung dengan persamaan:

$S=P \cdot \operatorname{Cos} \varphi$

B. Data Beban Tiap Penyulang

Tabel II

Data Beban Tiap Penyulang PT.PLN Sebatik

\begin{tabular}{|c|c|c|c|c|}
\hline No. & Feeder & $\begin{array}{c}\text { Daya } \\
\text { Output } \\
(\mathbf{k W})\end{array}$ & $\begin{array}{c}\text { Daya Semu } \\
\text { (kVA) }\end{array}$ & $\begin{array}{c}\text { Daya } \\
\text { Reaktif } \\
\text { (kVAR) }\end{array}$ \\
\hline 1 & 1 & 574 & 675,2941176 & 351,1529412 \\
\hline 2 & 2 & 678 & 797,6470588 & 414,7764706 \\
\hline 3 & 3 & 568 & 668,2352941 & 347,4823529 \\
\hline \multicolumn{2}{|c|}{ Jumlah } & 1820 & 2141,176471 & 1113,411765 \\
\hline
\end{tabular}

C. Data Kabel Tiap-tiap Penyulang PT.PLN Sebatik

Tabel III

Data Kabel Tiap-tiap Penyulang PT.PLN Sebatik

\begin{tabular}{|c|c|c|c|c|c|c|c|c|}
\hline \multirow[b]{2}{*}{ Z } & \multirow[b]{2}{*}{ 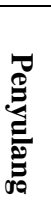 } & \multicolumn{5}{|c|}{ A3C } & \multirow{2}{*}{$\begin{array}{l}\mathbf{A 3 C S} \\
\text { N } \\
\hat{E} \\
E_{N}\end{array}$} & \multirow[b]{2}{*}{ 原 } \\
\hline & & 兰 & 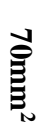 & 兑 & 胥 & 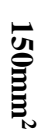 & & \\
\hline 1 & 1 & $\begin{array}{c}11,3 \\
\text { KMS }\end{array}$ & - & - & - & - & - & 11,3 \\
\hline 2 & 2 & 6,2 & - & - & - & - & - & 6,2 \\
\hline
\end{tabular}

\begin{tabular}{|c|c|c|c|c|c|c|c|c|}
\hline & & KMS & & & & & & \\
\hline 3 & 3 & $\begin{array}{c}42,4 \\
\text { KMS }\end{array}$ & - & - & - & - & - & 42,4 \\
\hline 4 & $\begin{array}{c}\text { Feeder } \\
\text { Express }\end{array}$ & - & - & - & - & 43 & - & 43 \\
\hline
\end{tabular}

Tabel IV

Data penghantar A3C (All Aluminium Alloy Conductor) (SPLN 64 1985)

\begin{tabular}{|c|c|c|c|c|c|}
\hline \multirow{2}{*}{$\begin{array}{c}\text { Luas } \\
\text { Penampa } \\
\text { ng } \\
(\mathbf{m m})\end{array}$} & \multirow{2}{*}{$\begin{array}{c}\text { Jari- } \\
\text { Jari } \\
(\mathbf{m m})\end{array}$} & \multirow{2}{*}{$\begin{array}{l}\text { Jumla } \\
\text { h Urat }\end{array}$} & \multirow{2}{*}{$\begin{array}{c}\mathbf{G M} \\
\mathbf{R} \\
(\mathbf{m m})\end{array}$} & \multicolumn{2}{|c|}{ Impedansi } \\
\hline & & & & $\begin{array}{c}\mathbf{R} \\
(\mathbf{O h m} / \mathbf{k} \\
\mathbf{m})\end{array}$ & $\begin{array}{c}\mathbf{X} \\
(\mathbf{O h m} / \mathbf{k} \\
\mathbf{m})\end{array}$ \\
\hline 35 & $\begin{array}{c}3,337 \\
1\end{array}$ & 7 & $\begin{array}{c}2,422 \\
7\end{array}$ & 0,9217 & 0.379 \\
\hline 50 & $\begin{array}{c}3,988 \\
6\end{array}$ & 7 & $\begin{array}{c}2,895 \\
7\end{array}$ & 0,6452 & 0,3678 \\
\hline 70 & $\begin{array}{c}4,719 \\
3\end{array}$ & 7 & $\begin{array}{c}3,426 \\
2\end{array}$ & 0,4608 & 0,3572 \\
\hline 95 & $\begin{array}{c}5,497 \\
9\end{array}$ & 19 & $\begin{array}{c}4,167 \\
4\end{array}$ & 0,3396 & 0,3449 \\
\hline 120 & $\begin{array}{c}6,179 \\
1\end{array}$ & 19 & $\begin{array}{c}4,683 \\
7\end{array}$ & 0,2688 & 0,3376 \\
\hline 150 & $\begin{array}{c}6,908 \\
4\end{array}$ & 19 & $\begin{array}{c}5,236 \\
5\end{array}$ & 0,2162 & 0,3305 \\
\hline 185 & $\begin{array}{c}7,672 \\
2\end{array}$ & 19 & $\begin{array}{c}5,815 \\
5\end{array}$ & 0,1744 & 0,3239 \\
\hline 240 & $\begin{array}{c}8,738 \\
6 \\
\end{array}$ & 19 & $\begin{array}{c}6,623 \\
8 \\
\end{array}$ & 0,1344 & 0,3158 \\
\hline
\end{tabular}

D. Data Transformator (Trafo) Tenaga

Tabel V

Data Transformator Tenaga

\begin{tabular}{|c|c|c|c|c|c|c|c|c|}
\hline \multirow[b]{2}{*}{ Z } & \multirow[b]{2}{*}{ Z्: } & \multirow[b]{2}{*}{ 쿵 } & \multirow[b]{2}{*}{$\begin{array}{c}\text { Kapa } \\
\text { sitas }\end{array}$} & \multicolumn{2}{|c|}{$\begin{array}{c}\text { Tegangan } \\
(\mathrm{kV})\end{array}$} & \multicolumn{3}{|c|}{$\begin{array}{c}\text { Tegangan } \\
\text { Toleransi \% }\end{array}$} \\
\hline & & & & $\begin{array}{c}\text { Pri } \\
\text { mar } \\
\mathbf{y}\end{array}$ & $\begin{array}{c}\text { Secon } \\
\text { dary }\end{array}$ & 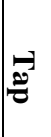 & $\begin{array}{c}\text { Pri } \\
\text { mar } \\
\mathbf{y}\end{array}$ & $\begin{array}{c}\text { Secon } \\
\text { dary }\end{array}$ \\
\hline 1 & $\begin{array}{c}\text { Traf } \\
\text { o } \\
\text { Uni } \\
\text { ndo }\end{array}$ & $\begin{array}{l}\text { ST } \\
\text { EP } \\
\text { UP } \\
01\end{array}$ & $\begin{array}{r}630 \\
\mathrm{kVA}\end{array}$ & 0,4 & 20 & $\begin{array}{l}2 \\
\times \\
2 \\
5 \\
5\end{array}$ & $\begin{array}{c} \pm \\
5 \% \\
\pm \\
10 \%\end{array}$ & $\begin{array}{l} \pm 5 \% \\
\pm 5 \%\end{array}$ \\
\hline 2 & $\begin{array}{c}\text { Traf } \\
\text { o } \\
\text { Uni } \\
\text { ndo }\end{array}$ & $\begin{array}{l}\text { ST } \\
\text { EP } \\
\text { UP } \\
02\end{array}$ & $\begin{array}{r}630 \\
\mathrm{kVA}\end{array}$ & 0,4 & 20 & $\begin{array}{l}2 \\
\times \\
2 \\
5 \\
5\end{array}$ & $\begin{array}{c} \pm \\
5 \% \\
\pm \\
10 \%\end{array}$ & $\begin{array}{l} \pm 5 \% \\
\pm 5 \%\end{array}$ \\
\hline 3 & $\begin{array}{c}\text { Traf } \\
\text { o } \\
\text { Uni } \\
\text { ndo }\end{array}$ & $\begin{array}{l}\text { ST } \\
\text { EP } \\
\text { UP } \\
03\end{array}$ & $\begin{array}{r}630 \\
\mathrm{kVA}\end{array}$ & 0,4 & 20 & $\begin{array}{l}2 \\
\times \\
2 \\
\\
5\end{array}$ & $\begin{array}{c} \pm \\
5 \% \\
\pm \\
10 \%\end{array}$ & $\begin{array}{l} \pm 5 \% \\
\pm 5 \%\end{array}$ \\
\hline 4 & $\begin{array}{c}\text { Traf } \\
\text { o } \\
\text { Uni } \\
\text { ndo }\end{array}$ & $\begin{array}{l}\text { ST } \\
\text { EP } \\
\text { UP } \\
04\end{array}$ & $\begin{array}{r}630 \\
\mathrm{kVA}\end{array}$ & 0,4 & 20 & $\begin{array}{l}2 \\
\times \\
2 \\
5 \\
5\end{array}$ & $\begin{array}{c} \pm \\
5 \% \\
\pm \\
10 \%\end{array}$ & $\begin{array}{l} \pm 5 \% \\
\pm 5 \%\end{array}$ \\
\hline 5 & $\begin{array}{c}\text { Traf } \\
0\end{array}$ & $\begin{array}{l}\text { ST } \\
\text { EP }\end{array}$ & $\begin{array}{r}630 \\
\mathrm{kVA}\end{array}$ & 0,4 & 20 & $\begin{array}{c}2 \\
\times\end{array}$ & \pm & $\pm 5 \%$ \\
\hline
\end{tabular}




\begin{tabular}{|c|c|c|c|c|c|c|c|c|}
\hline \multirow[b]{2}{*}{ z } & \multirow[b]{2}{*}{ 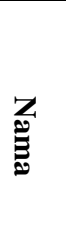 } & \multirow[b]{2}{*}{ 쿵 } & \multirow[b]{2}{*}{$\begin{array}{l}\text { Kapa } \\
\text { sitas }\end{array}$} & \multicolumn{2}{|c|}{$\begin{array}{c}\text { Tegangan } \\
(\mathrm{kV})\end{array}$} & \multicolumn{3}{|c|}{$\begin{array}{c}\text { Tegangan } \\
\text { Toleransi \% }\end{array}$} \\
\hline & & & & $\begin{array}{c}\text { Pri } \\
\text { mar } \\
\mathbf{y}\end{array}$ & $\begin{array}{c}\text { Secon } \\
\text { dary }\end{array}$ & ثै & $\begin{array}{c}\text { Pri } \\
\text { mar } \\
\mathbf{y}\end{array}$ & $\begin{array}{c}\text { Secon } \\
\text { dary }\end{array}$ \\
\hline & $\begin{array}{l}\text { Uni } \\
\text { ndo }\end{array}$ & $\begin{array}{l}\text { UP } \\
05\end{array}$ & & & & $\begin{array}{l}2 \\
\text {, } \\
5\end{array}$ & $\begin{array}{c}5 \% \\
\pm \\
10 \%\end{array}$ & $\pm 5 \%$ \\
\hline 6 & $\begin{array}{c}\text { Traf } \\
\text { o } \\
\text { Uni } \\
\text { ndo }\end{array}$ & $\begin{array}{l}\text { ST } \\
\text { EP } \\
\text { UP } \\
06\end{array}$ & $\begin{array}{r}630 \\
\mathrm{kVA}\end{array}$ & 0,4 & 20 & $\begin{array}{l}2 \\
\times \\
2 \\
, \\
5\end{array}$ & $\begin{array}{c} \pm \\
5 \% \\
\pm \\
10 \%\end{array}$ & $\begin{array}{l} \pm 5 \% \\
\pm 5 \%\end{array}$ \\
\hline 7 & $\begin{array}{c}\text { Traf } \\
\text { o } \\
\text { Uni } \\
\text { ndo }\end{array}$ & $\begin{array}{l}\text { ST } \\
\text { EP } \\
\text { UP } \\
07\end{array}$ & $\begin{array}{r}630 \\
\mathrm{kVA}\end{array}$ & 0,4 & 20 & $\begin{array}{l}2 \\
\times \\
2 \\
5 \\
5\end{array}$ & $\begin{array}{c} \pm \\
5 \% \\
\pm \\
10 \%\end{array}$ & $\begin{array}{l} \pm 5 \% \\
\pm 5 \%\end{array}$ \\
\hline 8 & $\begin{array}{c}\text { Traf } \\
\text { o } \\
\text { Uni } \\
\text { ndo }\end{array}$ & $\begin{array}{l}\text { ST } \\
\text { EP } \\
\text { UP } \\
08\end{array}$ & $\begin{array}{r}630 \\
\mathrm{kVA}\end{array}$ & 0,4 & 20 & $\begin{array}{l}2 \\
\times \\
2\end{array}$ & $\begin{array}{c} \pm \\
5 \% \\
\pm \\
10 \%\end{array}$ & $\begin{array}{l} \pm 5 \% \\
\pm 5 \%\end{array}$ \\
\hline
\end{tabular}

\section{HASIL DAN PEMBAHASAN}

A. Sistem Tenaga Listrik PT.PLN Sebatik

Penyaluran system tenaga listrik PT. PLN (Persero) Sebatik cabang berau ke beban listrik dengan mengoperasikan pembangkit listrik secara paralel. Sistem paralel digunakan agar daya listrik yang dihasilkan oleh pembangkit sesuai dengan beban listrik yang ada. Daya listrik yang disalurkan ke beban listrik melalui penyulang (feeder). Sistem tenaga Listrik PT. PLN (Persero) Sebatik cabang berau dibagi dalam 3 penyul sudut Total daya yang dibangkitkan dari semua pembangkit yang beroperasi di PT. PLN (Persero) Sebatik cabang Berau saat ini yaitu $2170 \mathrm{~kW}$. Cos $\varphi$ pada PT.PLN (Persero) Sebatik cabang Berau adalah 0.85 dan $\operatorname{Sin} \varphi 0.52$.

B. Pemodelan Sistem Tenaga Listrik

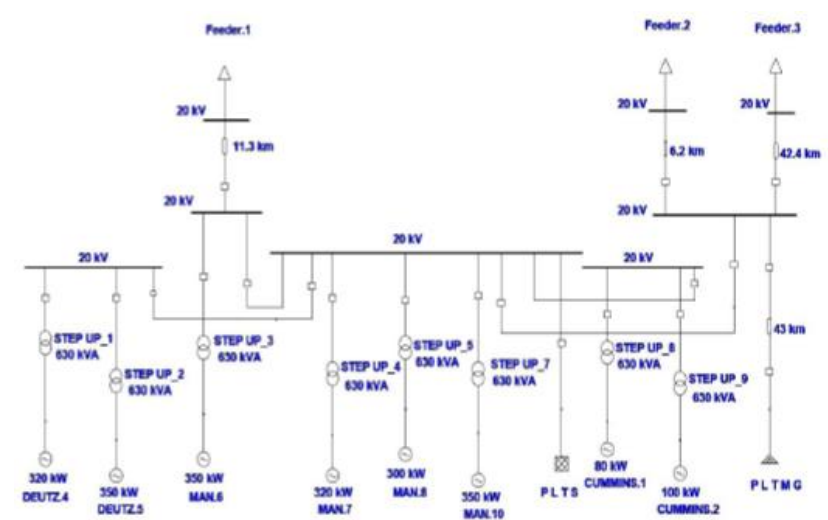

Gambar 10. Diagram segaris pabrik PT. PLN (Persero) Sebatik dalam ETAP 12.6.0
C. Simulasi Aliran Daya Software ETAP Power Station

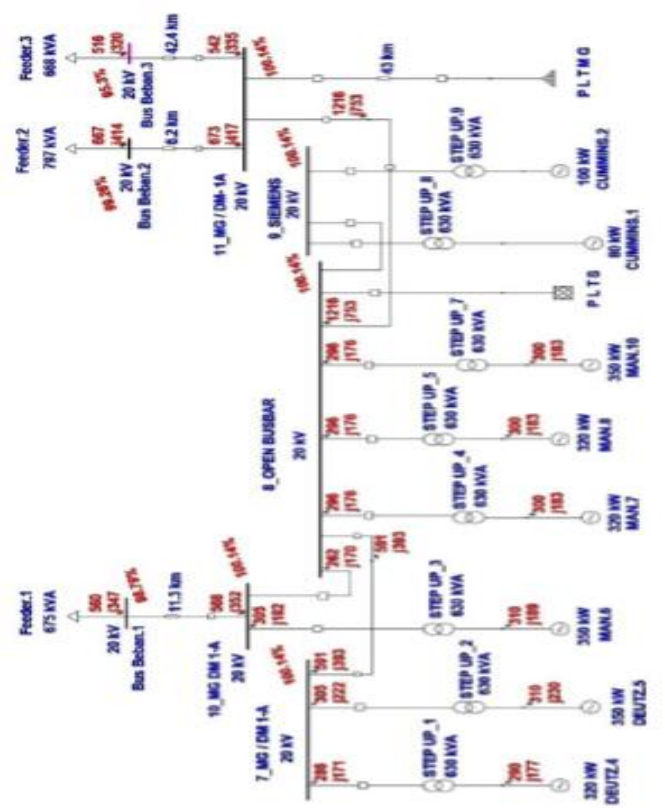

Gambar 11. Aliran daya pada kondisi beban puncak

Tabel VI

Loading/Beban bus kondisi beban puncak

\begin{tabular}{|c|c|c|c|c|c|c|}
\hline \multicolumn{2}{|l|}{ BUS } & \multicolumn{2}{|c|}{ Load/Beban } & \multicolumn{3}{|c|}{ Total BUS Load } \\
\hline ID & $\mathbf{k V}$ & MW & MVar & MVA & PF & Amp \\
\hline $\begin{array}{c}\text { 1_Bus } \\
\text { DEUTZ.5 }\end{array}$ & 0,4 & 0 & 0 & 0,386 & 80,3 & 557,5 \\
\hline $\begin{array}{c}\text { 2_Bus } \\
\text { DEUTZ.4 }\end{array}$ & 0,4 & 0 & 0 & 0,34 & 85,4 & 492,1 \\
\hline $\begin{array}{l}\text { 3_Bus } \\
\text { MAN.6 }\end{array}$ & 0,4 & 0 & 0 & 0,363 & 85,4 & 525,2 \\
\hline $\begin{array}{l}\text { 4_Bus } \\
\text { MAN.7 }\end{array}$ & 0,4 & 0 & 0 & 0,351 & 85,4 & 508,6 \\
\hline $\begin{array}{c}\text { 5_Bus } \\
\text { MAN.8 }\end{array}$ & 0,4 & 0 & 0 & 0,351 & 85,4 & 508,6 \\
\hline $\begin{array}{c}\text { 6_Bus } \\
\text { MAN.10 }\end{array}$ & 0,4 & 0 & 0 & 0,351 & 85,4 & 508,6 \\
\hline $\begin{array}{c}\text { 7_MG / DM } \\
1-\mathrm{A}\end{array}$ & 20 & 0 & 0 & 0,710 & 83,3 & 20,5 \\
\hline $\begin{array}{c}\text { 8_Open } \\
\text { BUSBAR }\end{array}$ & 20 & 0 & 0 & 1,742 & 84,8 & 50,2 \\
\hline 9_SIEMENS & 20 & 0 & 0 & 0 & 0 & 0 \\
\hline $\begin{array}{l}\text { 10_MG / } \\
\text { DM 1-A }\end{array}$ & 20 & 0 & 0 & 0,668 & 85 & 19,2 \\
\hline $\begin{array}{l}\text { 11_MG / } \\
\text { DM 1-A }\end{array}$ & 20 & 0 & 0 & 1,430 & 85 & 41,2 \\
\hline $\begin{array}{c}\text { 12_Bus } \\
\text { MG.2 }\end{array}$ & 20 & 0 & 0 & 0,710 & 83,3 & 20,5 \\
\hline 13 Bus MG & 20 & 0 & 0 & 1,430 & 85 & 42,1 \\
\hline Bus Beban.1 & 20 & 0,560 & 0,347 & 0,659 & 85 & 19,2 \\
\hline Bus Beban.2 & 20 & 0,667 & 0,414 & 0,785 & 85 & 22,8 \\
\hline Bus Beban.3 & 20 & 0,516 & 0,32 & 0,607 & 85 & 18,4 \\
\hline
\end{tabular}

D. Simulasi Hubung Singkat Satu Fasa ke Tanah

Setelah melakukan simulasi aliran daya kemudia dilakukan simulasi hubung singkat pada masing-masing bus. Untuk gangguan ini dapat dianggap fasa $a$ mengalami gangguan. Kondisi terminal pada saat terjadi gangguan hubung simgkat satu fasa ketanah adalah tegangan pada fasa yang mengalami gangguan sama dengan nol $(\mathrm{Va}=0)$, arus pada fasa $\mathrm{b}$ dan fasa $\mathrm{c}$ sama 
dengan $0(\mathrm{Ia}=\mathrm{Ib}=0)$. Masing-masing arus urutan sama besarnya $I_{1}=I_{2}=I_{0}$ dan arus urutannya sama dengan $1 / 3$ arus gangguan hubung singkat satu fasa ketanah (1/3Ia).

\section{E. Setelan Relai Arus Lebih}

Untuk setelan relai arus lebih yang terpasang di penyulang dihitung berdasarkan arus beban maksimum. Untuk relai invers biasanya diset sebesar 1,05 sampai dengan 1,1 x I beban, sedangkan untuk relai defininite diset sebesar 1,2 sampai dengan 1,3x I beban. Nilai arus tersebut merupakan nilai setelan pada sisi primer, yang akan disetkan pada relai adalah nilai sekundernya. Oleh karena itu dihitung menggunakan rasio terafo arus yang terpasang pada penyul sudut.

\section{F. Setelan Relai Hubung Tanah}

Untuk setelan arus di penyulang mengguanakan pedoman yaitu setelan arus gangguan tanah di penyulang diset $10 \% \mathrm{x}$ arus gangguan tanah terkecil penyulang tersebut.

\section{KESIMPULAN}

Besar arus gangguan hubung singkat satu fasa ke tanah pada penyulang $1=313 \mathrm{~A}$, penyulang $2=363 \mathrm{~A}$, penyulang $3=165 \mathrm{~A}$

1. Setelan relai arus lebih pada penyulang 1

Iset primer $=20,6 \mathrm{~A}$

Iset sekunder $=1 \mathrm{~A}$

2. Setelan relai arus lebih pada penyulang 2 Iset primer $=$ 23,9A

Iset sekunder $=1,2 \mathrm{~A}$

3. Setelan relai arus lebih pada penyulang 3

Iset primer $=19,3 \mathrm{~A}$

Iset sekunder $=0,6 \mathrm{~A}$

4. Setelan relai hubung tanah pada penyulang 1

Iset primer $=31,3 \mathrm{~A}$

Iset sekunder $=1,6 \mathrm{~A}$

5. Setelan relai hubung tanah pada penyulang 2

Iset primer $=36.3 \mathrm{~A}$

Iset sekunder $=1.8 \mathrm{~A}$

6. Setelan relai hubung tanah pada penyulang 3

Iset primer $=16.5 \mathrm{~A}$

Iset sekunder $=0.8 \mathrm{~A}$

\section{UCAPAN TERIMA KASIH}

Terima kasih penulis ucapkan kepada segenap pihak yang secara langsung maupun tidak langsung telah berkontribusi baik terhadap proses penyusunan tulisan ini maupun dalam proses publikasinya. Terima kasih kepada para autor yang naskahnya penulis jadikan sebagai referensi.

\section{REFERENSI}

[1] Affandi Irfan, Juni 2009,"Analisa Setting Relai Arus Lebih Dan Relai Gangguan Tanah Pada Penyulang Sadewa Di GI Cawang' Universitas Indonesia, Depok

[2] Amira, Juli 2014, "Studi Analisa Gangguan Hubung Singkat 1 Fasa Ke Tanah Pada SUTT 150 KV Untuk Setting Relay OCR (Aplikasi GI PIP - PAUH LIMO) ". Volume 3 No. 2, hal 96-97, 24 maret 2015

[3] Cekmas Cekdin, (2006). Sistem Tenaga Listrik. Palembang : Penerbit Andi Yogyakarta.
[4] Cekmas Cekdin dan Taufik Barlian. (2013). Transmisi Daya Listrik Palembang : Penerbit Andi Yogyakarta.

[5] Hidayat, Ade Wahyu, September 2013, "Analisa Setting Rele Arus Lebih dan Rele Gangguan Tanah pada Penyulang Topan Gardu Induk Teluk Betung ".Volume 7, No. 3, hal 109, 22 april 2015

[6] Kadarisma Pribadi, sarimun Wahyu.N, "Koordinasi OCR Dan GFR pada Jaringan Distribusi” : PT. PLN (Persero) Jasa Pendidikan dan Jasa Pelatihan Jakarta.

[7] Yoyok Triyono, Ontoseno Panangsang, jamsjul Alam, 2013,"Analisis Studi Rele Pengaman (Over Current Relay Dan Ground Fault Relay) pada Pemakaian Distribusi Sendiri dari PLTU Rembang" volume 2 No.2, hal 160, 4 oktober 2015, Institut Teknologi Sepuluh November, Surabaya. 